\title{
INCLUSIVE MUSIC EDUCATION IN THE SLOVAK REPUBLIC
}

\author{
Jaroslava Gajdošíková Zeleiová \\ University of Trnava, Slovakia \\ E-mail: jaroslava.zeleiova@gmail.com
}

\begin{abstract}
The Slovak educational system went through several changes the last 20 years, and these changes affected also the structure of music education. The aim of this paper is to point out the changes in educational system, stated in different national school documents, in the context of innovations and changes in musical education. The author analyses predominantly music education in the specialized primary school system, namely in primary art schools. They are positively evaluating as favourable influence of music education on meaningful exploitation of free-time, in connection with prevention of socially unwanted phenomena, its influence on full-value exploitation of children's free-time, observation and extension of components of regional culture in teaching and active share on cultural life of cities or villages, presentation in cultural undertakings, activity of various chamber ensembles in which pupils exploit and improve acquired abilities when practically playing in collective.
\end{abstract}

Key words: educational system in Slovakia, music education, music therapy, primary art schools.

\section{Introduction}

Socio-political, socio-cultural, and economical changes, which took place in the Slovak republic, necessitated radical legal changes and changes in educational organization, ideology and values in the field of education and its direction (National Programme for Education in the Slovak Republic for next 15-20 years, 2001). Complex socio-political and educational transformational scope of educational system is nowadays fulfilling itself gradually, by modificating of existing school laws or by passing new legal education-organizational and educational norms. Despite of economical and socio-political problems, modern approach of conception of content and organization of work in school transformation and in development of educational system was succeeded. These conceptions are gradually approximating to European standards-based education and the international standard classification of education.

\section{General and Art Education System}

Democratisation and restructuralization of the educational system, system of its direction, board of management, financing and implementation of new intentions of school policy, is drafted in the education law (Act No. 245/2008 on Upbringing and Education and on the change and supplement to some acts as amended by subsequent provisions). On the basis of current legislative scope, the actual educational system consists of:

- pre-school education and elementary schools,

- secondary schools and schools for students who didn't finish whole elementary school before finishing their compulsory school attendance, 
PROBLEMS

OF EDUCATION

IN THE $21^{\text {st }}$ CENTURY

Volume 48, 2012

24

- special schools - elementary, secondary, practical, and special training centres,

- schools for spare-time education - primary art schools,

- school institutions,

- universities - public, state, private, with three possible levels of university,

- institutions of continuous education for CPD (forms of further vocational, additional, extending, requalificational, civic, socio-cultural education), that are performed by different educational institutions and universities (Strategy of Lifelong Learning and Lifelong Guidance, 2007).

In the figure 1 are depicted currently existing individual types of schools (general and specialized), and levels of educational system in the Slovak republic according to the organization of the education system in Slovakia (Report of European Commission, 2010). Within a general education in elementary schools, musical education lessons are taught; in specialized musical education in primary art schools teaching of singing and playing musical instrument takes place. In the figure 1 are, for the sake of lucidity, mentioned only those schools and institutions from already mentioned educational system, that are more closely specified in the following lines and concern to the music.

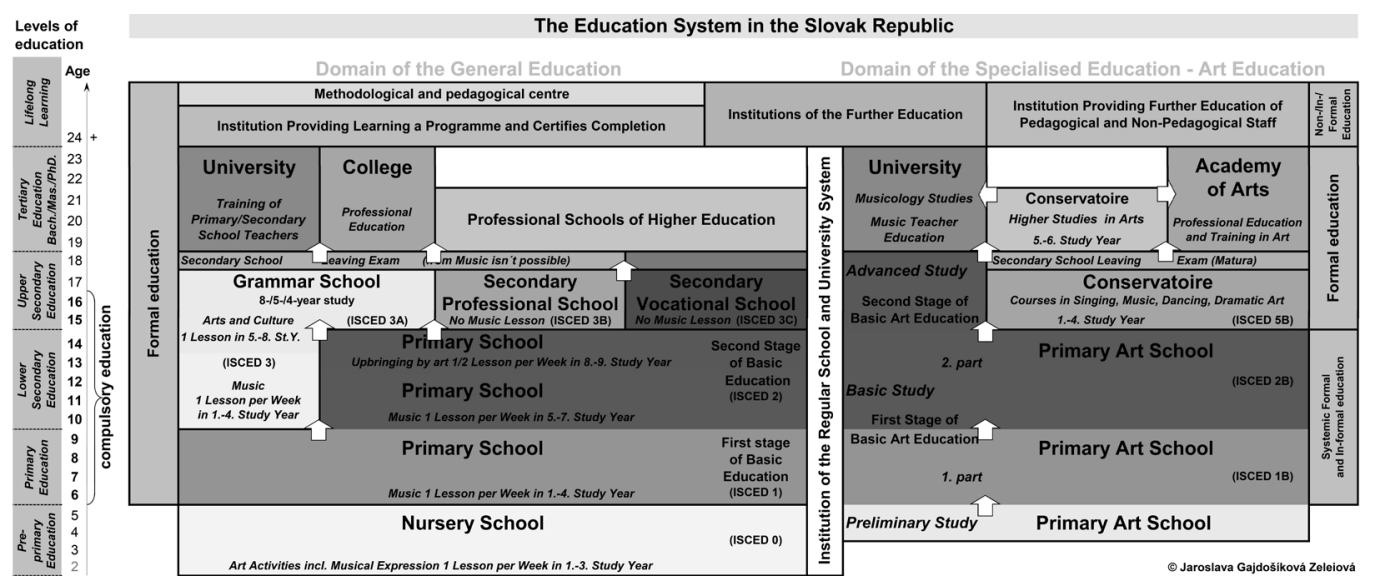

Figure 1: The Education System in the Slovak Republic.

Today's school system institutionaly cowers formal education, while informal systemic education is provided by primary art schools, and systemless is performed predominantly in educational institutions (school children clubs, centres of spare-time activities, centres of leisure time), and centres of further education. Centres of spare-time activities, functioning besides elementary schools and centres of leisure time, prepare rich scale of circles, seminars or projects also in the field of music. Thereby they support expansion of out-of-teaching and after school education, that was directly, within elementary schools, significantly weakened. The new conception of education in the Slovak Republic is synchronized with global European trends, requiring unification of degrees of education according to international classification ISCED (pre-primary, primary, lower and higher secondary, tertiary education). The new strategy of education through projecting of educational programs, is two-leveled: in the line of the National program of education for next 15-20 years are forming the State educational program (first level), and school educational programs (second level). On an individual levels of deciding about educational standards and contentual structure of education, participation of state and individual schools should be clearly defined. School educational programs should specify educational projects for individual schools, and in accordance with the State educational programme, school possibilities, and profilation of pupils, or with needs of local 
school surroundings, elaborate educational aims, and determine specific contentual structure of education: supporting by language-informational, social, mathematicaly-naturalscientifictechnical, and artistic literacy (Liebau, Zirfas, 2008). Evaluation of school educational program should be insured by the school itself and the State educational program monitored by National school inspection (Act No. 137/2005 on school inspection).

\section{Changes in Art Schools Policy}

After Slovakia entered the European Union in 2004, deepening of international intercourse and reciprocal cooperation of schools and school institutions remains our antecedent effort. It is, though, enacted in the space of socio-economical emulation, consisting of principle of allocating financial resources for school institutions and facilities according to number of pupils. On the background of institutional education occurs a fight for pupil/student, in which, for financial reasons, the quantity of educants is constrainedly preffered at the expense of quality of education. Economical aspect significantly decreased the quality of education during the last five years.

New legislative scope diversified tense system of unified educational system and school policy enabled establishing besides state schools also church and private schools, let us say alternative models of schools. Also academical institutions may have, according to founder, character of public, private or church university. The adjustment of school legislative partly enabled democratisation and decentralization of the system of management and administration of artistic school system (Figure 2), the principle of self-government and subsidiarity was attached, schools got the opportunity to gain legal subjectivity. This legislative change entailed considerable economical troubles that obstruct the creation of optimal conditions for following the curricula. The effort of headmasters and pedagogical staff to take hold in new economical conditions brings searching for more effective ways of solving financial problems - for example establishment of private schools, or transformation of state primary art schools and their merger into private sector, or establishment of already mentioned church combined elementary schools with art schools. In private primary art schools and in church primary art schools can be education provided only for payment, the level of which is not legislatively concluded. In purviews of European Union of musical schools it is necessary to ensure that state and autonomous authorities guaranteed enough financial resources for the operating of primary art schools.

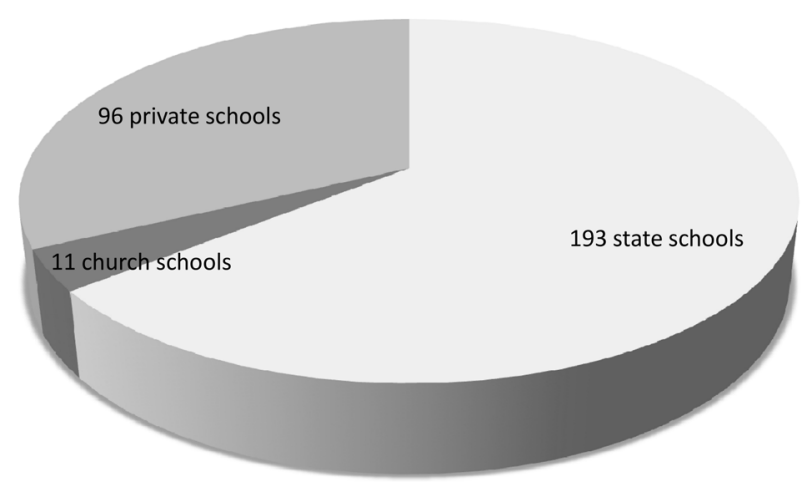

Figure 2: Diversification of primary art schools, their decomposition in the Slovak republic (source Institute of Information and Prognoses for Education, 2012). 
PROBLEMS

OF EDUCATION

IN THE $21^{\text {st }}$ CENTURY

Volume 48, 2012

Ongoing curricular transformation efforts succeed in modernization of content of education, publishing of new curricula with different variants, in creating, or innovating schedules for elementary and secondary schools, in accreditation of new educational programs at universities. Equally positive was the change of coiled content of teaching and educational standards at schools of art (The State educational programme for Primary Art School, 2008). More radical transformation is for Slovak educational system after ratification of education law. It should contribute to creating a plural market with textbooks and teaching scripts and support variability of methodical procedures. Educating of music teachers for comprehensive school went through numerous organizational and contentual changes, that were stimulated by National Institute for Education (2012) and its scientific-experimental, expert-methodical, and educational activity and Accreditation commission (2012). New qualifying conditions on expert-pedagogical competence of pedagogical staff were adjusted and their further lifelong education was ensured with the intention to reach compatibility with the European qualifications framework. Teachers have nowadays opportunity to educate themselves continuously, to take in specializational qualifying study, specializational inovative study and preparation for leaders of pedagogical staff (Act No. 445/2009 on continuous education, credits and attestations of pedagogical employees and professional employees).

In the field of gradual and post-gradual education of teachers, it is still important to ensure that educational programs, preparing future teachers of pre-primary, primary, and secondary education, will obtain higher temporal remuneration for artistic-educational subjects, and that teaching music education lessons will be specified. Demands on the qualification of musicalpedagogical staff should gradually meet international occupative standards (The Effects of the Bologna Declaration on Professional Music Training in Europe, 2012)

The school reform and curricular transformation entails important changes for existance of music lessons in elementary schools and musical education in primary art schools (Králová, 2009). Despite numerous positives and efforts to synchronize the Slovak tradition with European requirements, in the musical - pedagogical area raised questions about further movement and cultural education of the nation. Access to attainments and to culture is in European Union regarded as a significant factor of inventive progress and at the same time it is an indicator of the level of scholarship and of spiritual forwardness of the specific nation (Duncker, 2006).

Advancing of musical-pedagogical community in Slovak is confronted with the fundamental requirements of Charter about music education, valid for Central and Eastern Europe accepted by European Association for Music in Schools. Its main goals in the general education System in the Slovak Republic are (Medňanská, 2003):

- to ensure two hours of musical education in all levels of comprehensive schools, to create more space for collective play and musical hobby-groups,

- to establish musical education in secondary grammar schools and in other secondary schools, to enable school-leaving examination in music (at least as an optional subject),

- to ensure a special classroom, sufficiently equipped with quality musical instruments and with audio-visual technology in each school,

- to ensure the activity of collectives, cantorial and instrumental, in each school, and to integrate musical life of the school into the public life of near surroundings,

- to institute schools with enlarged musical education, as one of the ways to ensure professional youth,

- to ensure competent teachers for all types of schools in adequate number,

- to expand the education to music even for children in pre-school age.

Even though some of the requirements from Charter were enforced in our country even in the past, we didn't manage to implement all of them, or some of them only partly (Krušinská, 2010). The implementation of several of them is up to contemporary musical pedagogy. Integrative changes remarks also the informational-medial, cultural and musical-pedagogical 
formation of Slovakia. Without preservation, support and development of unique national cultures, it is impossible to create a plural European culture (Bamford, 2006). In Slovakia, however, the cultural identity - formed by musical-artistic educational system - remains on the brink of political interests in globalization trends, what is demonstrated even by delay of school and cultural reforms within long-term ongoing other social reforms. Changes in a new conception of school policy, that influence the area of music education, are predominantly as follows:

- establishment of zero class-year at elementary schools, what should help children coming from socialy and educationaly deficiently-stimulative background, or help and included children that have postponed compulsory school attendance, because of different reasons,

- by State educational programme incorporated right for children with special educational needs to integrate into classes for intact children (Convention on the rights of persons with disabilities, 2008).

\section{Changes in Primary Art Schools}

The concept of development of talented children and youth in the Slovak republic (2007) supports development of artistic talent in children and youth within the upbringing-educational process:

- the stage of interest: elective subjects in basic education, out-of-school education,

- the stage of performance: educational programs with extended music education, primary art school,

- the top stage: classes or schools for the gifted in art.

According to Law No. 245/2008 Coll. § 103 on Upbringing and Education institutional development of artistic talent in children or students is supported by primary art schools, school centers of spare-time activities, spare-time centers, conservatories, schools with extended educational program specialized in some artistic area (Figure 1). According to legislative,"primary art school provides special artistic education in particular artistic department and prepares students for teacher's and educational fields of study in secondary schools with artistic bearing and in conservatories; it prepares also for the universities with artistic or artistic-pedagogical bearing" (Act No. 245/2008 on Upbringing and Education and on the change and supplement to some acts as amended by subsequent provisions).

Primary art schools exist besides comprehensive schools as so-called schools for sparetime education, that don't ensure compulsory school attendance. Schools that enable specialized education afternoons are concerned. Primary art school establishes study fields as music, art, dance and literary-dramatic study field. In primary art schools, it is possible to establish musical, creative, dancing, and literary-dramatic departments, other than listed artistic departments can be established in a school with the approval of the Ministry of Education, Science, Research and Sport of the Slovak Republic (Act No. 245/2008 Coll. § 49). Pupils attend primary art school either for the reason that enables them to become artistic amateurs, or to prepare themselves for artistic career, later to qualify on other level of artistic educational system and to profile themselves to be productive artists. Primary art school guarantees art education and education according to the educational program of the given field of education especially for the students of elementary school:

- provides basic art education,

- prepares for the study of artistic subjects at secondary schools and conservatories,

- prepares for the study at universities specialized in pedagogy or arts.

The conservatory provides complex artistic and artistic-pedagogical education. It prepares students for artistic professions and teaching of artistic subjects (Act No. 245/2008 Coll. § 44). 
PROBLEMS

OF EDUCATION

IN THE $21^{\text {st }}$ CENTURY

Volume 48,2012

Primary art schools provide different age groups with the opportunity to expand their natural talent and emotional inteligence through music, dance, creative art or literarydramatical art. Socio-psychological-cultural potention of primary art schools in the field of educating young generation is not insignificant. As the existance of primary art schools consists of voluntary intake of artistic offers by children, the ability of meaningful and cultural existance forms naturally in themselves - even without further proffesional growth in higher type of artistic education - sensibilization of personality and positive enlargement of experiental world of young people that is very important for the development of their identity, is ensured.

The study in primary art school is organized for various age groups as:

- $\quad$ preliminary study ( max. 2 study years),

- $\quad$ the first stage of basic study (max. 9 study years): the first part (max. 4 study years) with primary artistic education and the second part (max. 5 study years) with lower secondary artistic education,

- $\quad$ the second stage of basic study (max. 4 study years),

- extended study (with extended number of study lessons for the extraordinary gifted students),

- shortened study (preliminary study for education at secondary schools, conservatories, universities specialized in pedagogy or art),

- $\quad$ study for adults (max. 4 study years). The stages of basic art education do not substitute for the pre-primary or basic education (Act No. 245/2008 Coll. § 17, §51).

Preparatory study in primary art school is generally assigned for children in pre-school age to diagnose artistic abilities of a child and its consecutive insertion into particular artistic department. Elementary study is assigned for pupils that have proved required level of their artistic abilities and habits enabling their further successful development in particular artistic department. In enlarged form of study, assigned for exceedingly gifted children, pupils can proceed according to individually adapted curriculum. In this type of study, the opportunity to prepare for further professional study is included, but only for playing musical instruments (absence of vocal education, intonation, auditive analysis, and musical-theoretical set-out). In preparation for teacher's study in pedagogical faculties, there is the opportunity to take in an enlarged study or study for adults. This form, though, is expanded only sporadically. Different factors - economical (so-called normative on pupil), socio-demographic (population regress, unattractivity of teacher's employment), legislative (insecurity of the existence and establishment of primary art schools) cause the regress of the interest in studying pedagogy in educational programs pedagogy of pre-primary and primary education, where, on some faculties, music-talented entrance examination are not required, but regression is also in the interest in pedagogy of secondary education with specialization on pedagogy of musical education. The followers of pedagogical study alone account weaker musical abilities, knowledge and practical instrumental handiness. This phenomenon reflects on the quality and standard of musical education in elementary school, where the graduates start their practice. There is a decrease of musical competence of future graduates - musical education teachers in schools. The study for adults is an offer for people who want to fill up their artistic education.

Several art schools have established the realization of new understanding of educating pupils with disabilities and disaffections. Primary art schools offer educational activities even for pupils with special educational needs too. The scientific community in Slovak cultural space accepts the implicit relationship between music education and music therapy within the systematic division of music-scientific and music-educational disciplines and their research circles (Gajdošíková Zeleiová, 2012). But explicit interconnection of music education and music therapy in curriculum has been absent in Slovakia so far, however, similarly aimed projects coordinating educational intentions with the therapeutic ones have existed in Euro-American space under the guarantee of organizations like the European Association for Music in Schools 
(EAS), European Music Therapy Confederation (EMTC), American Music Therapy Association (AMTA), International Society for Polyaesthetic Education (IGPE), Orff-Schulwerk Forum

etc. for several years. Considering the increasing socio-pathological and psycho-pathological manifestations of children/pupils, the interdisciplinary connection of education, psychology and music therapy seems to be an urgent challenge. Current European Commission proclamations in support and improvement of mental health (Green Papers) and proclamations concerning education towards the knowledge society (White Papers) have already been realized in projects such as Inclusion Europe, Autism Europe, Mental Health Europe or Open Society Mental Health Initiative, which point to inclusion of disordered, disabled and endangered citizens into all spheres of cultural life. The Slovak association of music therapy (2011) attempts to correspond with the above-mentioned socio-cultural challenges (Policy Guidelines on Inclusion in Education, 2009).

\section{Changes in Music Education}

Individual artistic fields - musical, creative, dancing and literary-dramatic - can be further subdivided. Pedagogical documents assignees in particular departments bearings in which a pupil compulsory attend main subject that is combined with musical theory, eventually with other subjects, and alternatively takes in, besides compulsory subjects, even voluntary (optional) subjects as well. Real reduction of temporal dotation of lessons in particular musical bearings results in restriction of chamber-music and four-handed playing, of corepeticion and optional subjects, such as improvisation. Curricula are, because of the influence of economical trends, not always strictly followed. The study of main subject in musical field is organized predominantly through individual teaching (The State educational programme for Primary Art School, 2008):

- preparation for instrument playing in preliminary study,

- playing musical instrument (piano, keyboard, violin, viola, violoncello, contrabass, harp, recorder, flute, piccolo, oboe, clarinet, saxophone, B and Es trumpet, cornet, French horn, trombone, baritone, helicon, tuba, bassoon, percussions, folk instruments, guitar, cymbalon, accordion, organ),

- singing,

- basis of musical composition. Through collective teaching the following musical subjects are performed:

- musical theory,

- chamber-music playing,

- playing in orchestra, choir,

- choir singing, liturgical singing,

- four-handed playing,

- instrumental accompaniment,

- the basis of conducting,

- music and computer,

- combo, a. o.

Positive steps of new, already established, but slowly realized contentual reform in school system concerning primary art schools from the point of view of musical department, are (Krušinská, Zeleiová, 2006):

- creation of private and church primary art schools, let us say their combination with comprehensive schools,

- assumption of modern or extra-european methods and models into artistic pedagogy (e.g. Suzuki's method, Yamaha music school), 
PROBLEMS

OF EDUCATION

IN THE $21^{\text {st }}$ CENTURY

Volume 48, 2012

30

- enabling of preparatory and enlarged form of study (in musical schools Yamaha since forth month of life up to seniors), offering the activities for pupils with special educational needs,

- establishment of primary art schools with enlarged teaching of aesthetical education,

- new concept of musical theory as an independent and equal subject with subjects such as playing musical instrument, with the imperative placed on musical perception and reception,

- teaching of musical theory through workshops and musical-educational projects for purpose of innovation and efectivization, building up technical ability on the basis of natural activities of playing ability, sublimation of musical-ear, harmonic feeling, emotive experience from interpreted composition supporting the expansion of creativity,

- activization of pupils through strategies expanding creative thinking while working with musical material, compared to mechanical reproduction and interpretation of composition without creative approach,

- implementation of multicultural and regional dimension into the content of musical theory for primary art schools,

- working with a musical work of art by using computer and multimedial technologies (Act No. 431/2007 on Concept of primary art education for provisiom of continuity of the system of art education with gradual introduction of ICT and multimedia education in the educational process of these schools),

- motivating pupils through competitions in artistic interpretating and team knowledge quiz from the field of musical theory and the history of music,

- establishment of new musical bearings, such as keyboard playing, music and computer, musical composition, combo, opportunity to play on electroacoustic instruments, a.o.,

- creation new textbooks of musical theory for primary art schools and methodical handbooks, a. o.

Consistent exercitation of the positives of curricular reform in primary art schools is however often blocked by economical and (thence it's followed by) professional defections. Average materially-technical equipment of schools (rusty musical instruments, didactic and computing techniques and other teaching aids) is well below the European standards and precludes consequent realization of actual reforming conveniences. However, in spite of the lack of financial capital, Slovak graduates of primary art schools produce excellent results in national and foreign artistic competitions with European prestige. In transformation of music education in primary art schools, there is still need to reissue or to publish new textbooks of musical theory for higher year-classes and to ensure musical audio CDs corresponding with particular lessons in textbooks, let us say offer variability of teaching materials. In conceptual intention of artistic schools it is possible to observe the tendency to adapt to parents' requirements demanding the establishment of new bearings in musical field (e.g. guitar playing, keyboard playing, improvization, electronical processing of sound record), but without competent personal assurance. Trend of compromise has negative effect on the quality of teaching and on absence of musical-pedagogical research and grant activities of primary art schools (Bresler, 2007). Partly downtrend to decreasing professionality in teaching is surely the result of elimination of individual approach thanks to new economical, sociological and legislative situation - in primary art schools as well as in universities in the programs preparing future teachers of preprimary, primary, secondary, and for still existing artistic education.

The results of scale factors in the effectivity of pedagogue's activity, teaching condition created by a pedagogue, effectivity of teaching, effectivity of pupils' activity, pupils' knowledge and abilities, pupils' educational results and verbal evaluation, monitored in main departments in primary art schools by the National School Inspection, don't bear evidence seemingly for the quality of education in musical department. The problem of different final effects can be 
interpreted also in consideration of the style of individual and grouped, let us say collective teaching. In comparison to musical department, in all other departments of primary art school the teaching is performed in grouped/collective form, where the imperative is placed on group dynamics, cooperation, and reciprocal instigation of inspirations, initiatives, and ideas. Individual approach to pupils is most significant right in musical department. Such a different number of pupils may influence quantitative and qualitative interpretation of indicators, let us say differentiate normotypologicaly used methodics of monitoring the teaching (Report on the status and level of education, 2011). If the criterion of the effectivity of music education on primary art schools will be their financial profitability, it will be difficult to reach it besides quality, and at the same time mainly individual teaching in musical department. The question, that remains unanswered for a long time, is the choice of either quantity or quality.

In spite of decreasing of the quality of teaching in primary art schools, National school inspection (2011) in overall monitoring positively evaluates:

- favourable influence of artistic education on meaningful exploitation of free-time, in connection with prevention of socially unwanted phenomena, its influence on fullvalue exploitation of children's free-time,

- observation and extension of components of regional culture in teaching and active share on cultural life of cities or villages,

- presentation in cultural undertakings in Slovakia and abroad,

- activity of various chamber ensembles in which pupils exploit and improve acquired abilities when practically playing in collective.

Other positive impacts of primary art school on formation of national culturality:

- socio-emotional growth of pupils' personalities,

- positive influence on children's moral and social values orientation,

- operating of choirs and chamber ensembles in local and wider cultural space, and formation of natural cultural life in cities and villages,

- primary art schools, representing schools with aesthetical character, are a significant culturally-educational agent of social environment, and in education of pupils apart from classes.

Experience shows that individual form of teaching can naturally, explicitly and effectively support unique personal and efficient characteristics of pupils. Individual aspect in teaching - economically least advantageous and financially rather ineffective - has a significant measureless implication on child's development. It supports spontaneous and healthy formation of young human's identity, indirectly it gives him/her lessons of open communication, personal and committed approach to phenomena all around, it instigates creation of his/her attitudes and opinions that are formed directly under the influence of emotional and personal relations to experienced facts. In regard to actual, involuntary prefered quantity of teaching in primary art schools in Slovakia, individual approach remains a positive challenge in teaching. In wholesocially known crisis of young people's identity, psychological and sociological indicators of education are plumbless.

\section{Conclusions}

In comparison to teaching musical education and existence of musical schools in original western countries of European Union that have secured wide musical hinterland by sufficient temporal dotation and contentual variability in comprehensive schools, through what they partly compensate the absence of network of primary art schools, in Slovakia we are not yet able to ensure a general artistic, and especially musical literacy in teaching in comprehensive schools. Artistic institutional system, created in Slovakia, in the European context can contribute for national-cultural awareness and artistic literacy of following generations.

\author{
PROBLEMS \\ OF EDUCATION \\ IN THE $21^{\text {st }}$ CENTURY
}


PROBLEMS

OF EDUCATION

IN THE $21^{\text {st }}$ CENTURY

Volume 48, 2012

The possibility to take children in artistic education at the age of 5, and the chance to continually grow and expand one's talent and personality right up to the adulthood, is, from the point of view of healthy formation, an natural systematized space, in which a child can unwillingly learn how to make use of free-time actively and meaningfully, and how to differentiate not only aesthetic values, but also the social and moral ones. Properly organized and institutionalized education that actual network of primary art school enables, form the young generation artistically as well as personally. Orientation and exploitation of space for personal creative self-realization - that child discoveres in art - is later analogically transferred into social and working space. Primary art schools participate significantly on the prevention of socio-pathological phenomena, so they are not just schools that educate and professionally prepare pupils for their career in the field of art. They represent schools that contribute predominantly to the formation of human resources on high quality level.

At present music education faces challenges that are brought by the changes in social status of music and the accelerated psychosocial personality development under the influence of the development of information and communication technologies and media. Reality, which a young person grows up in and acquires a spontaneous or institutionally mediated experience in the process of education, influences their overall formation and possibilities of capturing the information necessary for a meaningful and effective functioning in a society. In the background of the socially perceived relativization, of the one-sided - and thus reduced - value preference and dynamizing lifestyle, respectively, there are questions that emerge within the scope of music education. These questions concern efficiency of the intermediation ways of music-aesthetic experience and music-aesthetic competences acquisition with the support of the global recognition of reality and integral development of a person.

\section{Acknowledgment}

The study was prepared with the financial aid of the Cultural and Educational Grant Agency 009TTU-4/2011 of the Ministry of Education, Science, Research and Sport of the Slovak Republic in the project Inclusive Education as a multidimensional problem.

\section{References}

Act No. 445/2009 on Continuous Education, Credits and Attestations of Pedagogical Employees and Professional Employees. Decree of the Ministry of Education of the SR on October 19, 2009.

Act No. 137/2005 on School Inspection. Decree of the Ministry of Education of the SR on March 31, 2005.

Act No. 245/2008 on Upbringing and Education and on the change and supplement to some acts as amended by subsequent provisions. Law of the Ministry of Education of the SR on May 22, 2008.

Bamford, A. (2006). The wow factor: global research compendium on the impact of the arts in education. Münster - New York - München - Berlin: Waxmann Verlag.

Bresler, L. (Ed.) (2007). International Handbook of Research in Arts Education. Dordrecht: Springer Netherlands.

Convention on the rights of persons with disabilities. (2008). Statement No 317/2010 of Ministry of Foreign and European Affairs of the SR.

Duncker, L. (2006). Ästhetische Alphabetisierung als Bildungsaufgabe. Kursiv: Journal für politische Bildung, 2 (1), 12-24.

Gajdošíková Zeleiová, J. (2012). Psychodynamic Aspects of Music Therapy. Music-Educational and Music-Therapeutic Contexts. Trnava: Typi Universitatis Tyrnaviensis, Musica Therapeutica.

Institute of Information and Prognoses for Education. (2012). Retrieved May 1, 2012 from www.uips. sk/registre.

Králová, E. (2010). Integration of Music into Standard Education of Arts and Crafts as Means of Easing Transitions to Middle School. Journal of Young Scientists, 2 (27), 33-38. 
Krušinská, M. (2009). Výchova k hudbe v škole Márie Montessoriovej. Podnety pre teóriu a prax hudobnej výchovy v alternativnych a inovativnych modeloch škôl na Slovensku. Ružomberok: KU.

Krušinská, M., Zeleiová, J. (2006). Hudobná edukácia na Slovensku po roku 1989 so zameraním na základné školy a základné umelecké školy: tradícia a inovácia. Musicologica Slovaca et Europaea, $X X V(1), 29-62$.

Liebau E., Zirfas, J. (Eds.) (2008). Die Sinne und die Künste. Perspektiven ästhetischer Bildung. Bielefeld: Transcript.

Medňanská, I. (2003). Existuje európska hudobná pedagogika? Kultúrna politika EÚ - zakotvenie v Maastrichtskej zmluve. E-Pedagogium, 3 (1), 42-55.

Millenium - National Programme for Education in the Slovak Republic for next 15-20 years. (2001). Bratislava: Institute of Information and Prognoses for Education.

National Institute for Education. (2012). Retrieved September 25, 2012 from http://www.statpedu.sk

Organisation of the education system in Slovakia. Report of European Commission. (2010). Retrieved September 25, 2012 from http://eacea.ec.europa.eu/education/eurydice/documents leurybase/eurybase_full_reports/SK_EN.pdf

Policy Guidelines on Inclusion in Education. (2009). Paris: United Nations Educational, Scientific and Cultural Organization. ED-2009/WS/31

Report on the status and level of education. (2011). Bratislava: National school inspection. Retrieved August 25, 2012 from http://www.ssiba.sk/Default.aspx?text=g\&id=2\&lang=sk

Slovak association of music therapy. (2011). Accredited by the Ministry of Interior of the SR on Juli 28, 2011. Retrieved September 25, 2012 from http://www.muzikoterapia.eu

Strategy of Lifelong Learning and Guidance. (2007). Bratislava: Ministry of Education of the SR.

The Concept of Development of Talented Children and Youth in the Slovak republic. (2007). Bratislava: Ministry of Education of the SR.

The Concept of Primary Art Education for provision of continuity of the system of art education with gradual introduction of ICT and multimedia education in the educational process of these schools. Act No. 431/2007. Decree of the Ministry of Education of the SR on May 16, 2007.

The Effects of the Bologna Declaration on Professional Music Training in Europe. (2012). The Project of European cultural and educational network. Retrieved September 25, 2012 from www.aecinfo. org/bologna.html

The State Educational Programme for Primary Art School. ISCED 1B, ISCED 2B. (2008) Bratislava: National Institute for Education.

Advised by Judita Stankutè, SMC “Scientia Educologica”, Lithuania

Received: October 03, 2012

Accepted: November 13, 2012

\begin{tabular}{|l} 
PROBLEMS \\
OF EDUCATION \\
IN THE 21 $1^{\text {st }}$ CENTURY \\
Volume 48, 2012 \\
\hline 33
\end{tabular} 